\title{
LAW PROTECTION FOR INDONESIAN MIGRANT WORKERS FAMILY IN CIANJUR DISTRICT ${ }^{\Omega}$
}

\author{
Tanti Kirana Utami \\ Faculty of Law, Universitas Suryakancana, Indonesia \\ E-mail: kireinatanti78@gmail.com
}

\begin{abstract}
Cianjur as one of districts where migrant workers origin should have Local Government's concern in terms of legal protection for both workers (TKI) and their families to achieve the family resilience and welfare. This paper examines how the protection model of TKI and their families and how its implementation. This research uses normative juridical type by case approach. This is a descriptive research by applying triangulation method. The research result shows that the model of protection for TKI and families in Cianjur district is activity programs for economic empowerment among TKI families. These programs are implemented through forming Bina Keluarga (BK-TKI)/migrant workers family programs at District level, BK-TKI at sub-district level and BK-TKI at village level. Therefore, the Migrant workers and families issue should be comprehensively and structurally conducted between government and society.
\end{abstract}

Keywords: migrant workers family program, protection model, economic empowerment.

\begin{abstract}
Abstrak
Kabupaten Cianjur termasuk kabupaten yang cukup banyak mengirimkan Tenaga Kerja ke Luar Negeri, untuk itu Pemerintah Daerah berupaya untuk melindungi TKI dan keluarganya dengan tujuan mewujudkan tercapainya ketahanan dan kesejahteraan keluarga. Tulisan ini menelaah tentang bagaimanakah model perlindungan keluarga tenaga kerja Indonesia di Kabupaten Cianjur dan bagaimanakah teknik pelaksanaan perlindungan keluarga tenaga kerja Indonesia di Kabupaten Cianjur. Penelitian ini menggunakan jenis yuridis normatif dengan cara pendekatan kasus. Spesifikasi penelitian deskriptif analisis, dan analisis data menggunakan metode triangulasi. Hasil dari penelitian ini adalah Model perlindungan keluarga tenaga kerja Indonesia di kabupaten cianjur adalah dengan cara membuat program kegiatan yang bertujuan pemberdayaan ekonomi bagi keluarga TKI. Teknik pelaksanaan perlindungan keluarga tenaga kerja Indonesia di Kabupaten Cianjur adalah dengan cara membentuk kelompok Bina Keluarga (BK-TKI) di tingkat Kabupaten, BK-TKI tingkat Kecamatan dan BK-TKI tingkat desa/ kelurahan. Oleh karena itu, penanganan permasalahan TKI dan keluarganya harus dilakukan secara komprehensif dan terstruktur antara pemerintah dengan masyarakat.
\end{abstract}

Kata kunci: bina keluarga TKI, model perlindungan, pemberdayaan ekonomi.

Introduction

Employment development as part of the national development is based on Pancasila and the 1945 Constitution. It is implemented to enhance Indonesian people development including to increase worker's dignity, self esteem for prosperous and fair citizens. ${ }^{1}$

$\Omega \quad$ This paper is part of the research with title "Model Perlindungan Hukum Bagi Keluarga Tenaga Kerja Indonesia Di Kabupaten Cianjur Dalam 330.a/DEK-FH/UNSUR/KEP/ $\mathrm{X} / 2017$.

1 Herdy L. N Pihang, "Tanggung Jawab Perusahaan Jasa Tenaga Kerja Indonesia (PJTKI) Terhadap Perlindungan
Speaking employment concept, human make living for reasons. They work for money to fulfil their necessities. For very traditional communities, they largely depend on nature while the modern society recognize a task differentiation in fulfilling their need by producing goods or providing services. In regards to this, the human needs is classified into physiological, social, and egoistic needs. ${ }^{2}$ For human, employ-

Tenaga Kerja Wanita”, Jurnal Lex Et Societatis, Vol. I No. 5, September 2013, p. 64.

2 Sri Hartini and Abdul Aziz Nassihudin, "Pengisian Jabatan Sekretaris Desa Di Kabupaten Banyumas (Studi Ten- 
ment is fundamental. Then the important meaning of job for people is reflected in the Constitution 1945 Article 27 section (2) ${ }^{3}$. Any attempts of realization of law fulfillment and employment protection was executed in 2003 by Law Number 13 Year 2002 on employment. ${ }^{4}$ In the globalization era, going abroad has been a common thing for Indonesia Citizens in terms of certain purposes. Among them are TKI (Indonesian Migrant Workers). ${ }^{5}$

The number of Indonesian workers has become a big potential as a capital in development. Therefore, development is one thing to consider in terms that how the capital can be developed and in accordance with its development function in the development itself, including the availability of employment. Nowadays, there are many ways and attempts to establish and prepare the employment for Indonesian people like formal or informal employment, one of which is sending Indonesian workers abroad. ${ }^{6}$ According to the Population Control Office, Family Planning, Women Empowerment and Children Protection in Cianjur District (DPP KBP3A Cianjur), the number of Indonesian workers from Cianjur in 2015 that work either overseas or domestic as assistants is about 19.681 and 19.498 people.

The TKI protection is a big effort to secure TKI/TKI applicant's right based on law regulation, either before, during, or after the work. ${ }^{7}$ Article 1 Number 1 Regulation of State Ministry of Indonesian Women Empowerment and Children Protection Number 20 Year 2010 on gene-

tang Kebijakan Pengisian Jabatan Sekretaris Desa)", Jurnal Dinamika Hukum, Vol 8 No 1 January 2008, p. 15.

3 Adharinalti, "Perlindungan terhadap Tenaga Kerja Indonesia Irregular di Luar Negeri", Jurnal rechtsvinding, Vol. 1 No. 1, April 2012, p. 157.

4 Netty Endrawati, Perlindungan Hukum Terhadap Pekerja Anak di Sektor Informal (Studi Kasus di Kota Kediri), Jurnal Dinamika Hukum, Vol. 12 No. 2, May 2012, p. 271.

5 Peni Susetyorini, "Perlindungan Tenaga Kerja Indonesia (TKI) di Luar Negeri Oleh Perwakilan Republik Indonesia", Jurnal Masalah-masalah Hukum, Jilid 39 No. 1, March 2010, p. 65.

6 Erwan Baharudin, “Perlindungan Hukum Terhadap TKI Di Luar Negeri Pra Pemberangkatan, Penempatan, Dan Purna Penempatan", Lex Jurnalica, Vol. 4 No. 3, August 2007, p. 170.

7 Agusmidah, 2010, Hukum Ketenagakerjaan Indonesia, Dinamika dan Kajian Teori, Jakarta: Ghalia Indonesia, p. 85. ral guidance for TKI's family states that the local government and society must guide TKI family through economic empowerment for the realization of TKI family resilience and welfare for their life quality enhancement. The problem faced by TKI and their family is so com-plex and broad that preventive action which is comprehensive between the government and so-ciety is required.

Undeniably, TKI of Cianjur that work overseas almost deal with economy matter, the harmony of family as well as the growth of child. That is why law protection and guidance is needed not only for the TKI, but also the family members. In regard to this, it is necessary to examine on how the guidance and law protection for the TKI family members in Cianjur. This study concerns about law protection model for TKI family members in Cianjur and the technique of implementation of TKI family guidance in Cianjur.

\section{Research Method}

This research employs normative juridical by case approach through descriptive analysis. The research was conducted in Cianjur district. Then, the primary data is taken from an interview with people involved and the secondary data as the main data resource are in form of Law Regulation which is Law Number 52 Year 2009 on Society Development and Family Establishment, Regulation of State Ministry of Indonesian Women Empowerment and Children Protection Number 20 Year 2010 on general guidance for TKI's family and local regulation of Cianjur district No. 01 Year 2012 on the placement and protection of TKI Cianjur to go abroad supported by books and journals.

The technique of data collection and analysis is taken from bibliography and field data (DPPKBP3A Cianjur). Data analysis is then conducted through qualitative method by triangulation method. The triangulation is a model circle check that the research data gained can be counted as valid and reliable.

\section{Discussion}




\section{The Law Protection of Indonesian Migrant Workers Family In Cianjur}

The Provision of Article 27 verse(2) Article $28 \mathrm{D}$ verse (2) Constitution 1945 is the Idea of Law Employment of Indonesia in accordance with the national economy development goals adopting Pancasila economy democracy concept that will realize the prosperity for the whole Indonesia citizens. ${ }^{8}$ Indonesia implement law state concept that is improved to its purposes which is nation prosperity. In the concept of nation prosperity, not only the government acts as defender of society, but also is responsible to realize the social justice and social prosperity.

Law is not a purpose but it is a reflection of the social aspiration within the protection of rights, individual purposes that is put in the norms of law or law principle is the connector that will bring the whole society of Indonesia to the expected ideas. ${ }^{9}$ Henny said that one of determinant factors in holding power is norm or law. ${ }^{10}$ Article 3 Law No.13 Year 2003 on the Employment explains that the establishment of employment implemented based on the fusion principle through functional coordination based on central and local sector with its purpose to make true of social justice in the employment sector, especially in the protection of TKI. The law that regulates the law protection for the TKI is Law Number 39 Year 2004 on the Placement and Protection of TKI overseas.

Sending Indonesian Migrant Workers overseas is a program of employment management in Indonesia as agenda of employment expansion. Moreover, it is to increase TKI competence, skill and prosperity. In implementing national development, migrant workers play an important role as actor and as the development

8 Ahmad Hunaeny Zulkarnaen and Tanti Kirana Utami, "Perlindungan Hukum Terhadap Pekerja Dalam Pelaksanaan Hubungan Industrial”, Padjadjaran Jurnal IImu Hukum, Vol. 3 No. 2, 2016, p. 409.

9 Sunaryati Hartono, 1991, Politik Hukum Menuju Sistem Hukum Nasional, Bandung: Alumni, p. 1.

10 Henny Nuraeny and Tanti Kirana Utami, "The Victim Handling Model of Human Trafficking through Economic Independence", Jurnal Dinamika Hukum, Vol. 16 No. 2, May 2016 p. 121. goal. ${ }^{11}$

The Provision of Article 2 of State Ministry of Indonesian Women Empowerment and Children Protection Regulation Number 20 Year 2010 on general guidance for TKI family explains that TKI is every Indonesian people who fulfill the requirement to work overseas, who is working or has been working overseas and needs guidance by local government and society. Considering the importance of TKI in achieving foreign exchange, thus a policy to give TKI protecttion is needed. In this case, Indonesia is suggested to learn from Philippine with their Philippine's Employment Overseas Administration (POEA). ${ }^{12}$

Government policy in facilitating TKI placement overseas is one of the efforts to decrease the number of unemployment. This policy also wants to realize equal rights and chances for every person whether men or women as worker to get job and decent income. In other side, it cannot be avoided that sending TKI to other country can give additional large foreign exchange. Nevertheless, the other problem arises especially TKI family. For instance, the family member's incompetence in managing the transferred money, husband and wife long distance relationship, and unwell children parenting.

The number of TKI increases every year dominated by women. Generally, they work in informal sector as housekeeper, farm sector, production sector in factories and etc. The number of overseas TKI placement until February 2010 (Kemnakertrans, 2010) had reached 2.679.536 people (two million six hundred seventy nine thousand and five hundred thirty six), meanwhile the foreign exchange income from remittance sent by TKI until the end of 2009 was US\$ 6.615.321.274 billion.

\footnotetext{
1 Citra Berlian Butsi, Saleh Soeaidy, Minto Hadi, "Efektivitas Program Asuransi Tenaga Kerja Indonesia (Tki) Sebagai Upaya Pemenuhan Hak-Hak TKI (Studi Pada Unit Pelaksana Teknis Pelayanan penempatan Dan Perlindungan Tenaga Kerja Indonesia Surabaya)", Jurnal Administrasi Publik (JAP), Vol. 1 No. 7, p. 1313.

12 S. Djuni Prihatin, "Potret Buram Perlindungan Tenaga Kerja Indonesia”, Jurnal Ilmu Sosial dan Ilmu Politik, Vol. 10 No. 3, Maret 2007, p. 335.
} 
TKI who works overseas and leaves their family is vulnerably affected to economic problem and family harmonization that influenced children development. Therefore, guidance for TKI family is required. TKI Protection aims to guarantee the basic rights of TKI and opportunity equality as well as free-discrimination treatment to realize TKI and their family prosperity by still paying attention to the business world progress. ${ }^{13}$

The problems suffered by TKI and their family are complex and wide. In this case there are three main problems: poor money management by family of TKI who work overseas, family disharmony that causes cheating and divorce, and unwell children parenting. It is inline with Henny's opinion that "Child is one of objects vulnerable to right violation", thus, they need to be protected. ${ }^{14}$

Regulations dealing with TKI family protection in Cianjur district are: Law Number 52 Year 2009 on The Development of Population and Family, Regulation of State Ministry of Indonesian Women Empowerment and Children Protection Number 20 Year 2010 on general guidance for TKI family, Cianjur Local Regulation Number 03 Year 2010 on Human Trafficking Prevention, Cianjur Local Regulation Number 01 Year 2012 on Placement and Protection of Cianjur TKI Overseas. Cianjur Local Regulation Number 06 Tahun 2015 on Children Protection. Data of the number of TKI who work both overseas and domestic as housemaid can be seen in table bellow.

Table 1. The composition of TKI Cianjur distribution

\begin{tabular}{llcc}
\hline NO & \multirow{2}{*}{ DISTRICT } & \multicolumn{2}{c}{ Work } \\
\cline { 3 - 4 } & & Overseas & Domestic \\
\hline 1 & Cianjur & 719 & 698 \\
2 & Warungkondang & 640 & 300 \\
3 & Cibeber & 1.192 & 1.523 \\
4 & Cilaku & 267 & 423
\end{tabular}

13 Rahadi Wasi Bintoro, Riris Ardhanariswari, Rahman Permana, "Implementasi Uu No. 13 Tahun 2003 Tentang Ketenagakerjaan Bagi Tenaga Kerja Perempuan Di Kabupaten Purbalingga", Jurnal Dinamika Hukum, Vol. 8 No. 3, September 2008, p. 232.

14 Henny Nuraeny and Tanti Kirana Utami, “Legal Protection Against Children Who Are Victims Of Human Trafficking In Cianjur District Studied By Human Rights Perspective", Jurnal Dinamika Hukum. Vol. 15 No. 2 May 2015, p. 172.

\begin{tabular}{clcc}
5 & Ciranjang & 715 & 299 \\
6 & Bojongpicung & 1.752 & 558 \\
7 & Karangtengah & 663 & 691 \\
8 & Mande & 333 & 648 \\
9 & Sukaluyu & 1.536 & 415 \\
10 & Pacet & 82 & 61 \\
11 & Cugenang & 941 & 499 \\
12 & Cikalongkulon & 821 & 1.035 \\
13 & Sukaresmi & 367 & 240 \\
14 & Sukanagara & 318 & 481 \\
15 & Campaka & 346 & 752 \\
16 & Takokak & 596 & 851 \\
17 & Kadupandak & 332 & 787 \\
18 & Pagelaran & 469 & 190 \\
19 & Tanggeung & 783 & 1.237 \\
20 & Cibinong & 937 & 1.233 \\
21 & Sindangbarang & 853 & 1.406 \\
22 & Agrabinta & 423 & 197 \\
23 & Cidaun & 1.157 & 479 \\
24 & Naringgul & 200 & 654 \\
25 & Campakamulya & 220 & 150 \\
26 & Cikadu & 757 & 772 \\
27 & Gekbrong & 369 & 650 \\
28 & Cipanas & 147 & 158 \\
29 & Cijati & 427 & 589 \\
30 & Leles & 292 & 95 \\
31 & Haurwangi & 429 & 186 \\
32 & Pasirkuda & 598 & 1.241 \\
\hline & TOTAL & 19.681 & 19.498 \\
\hline Source: Family data collection $(P K)$ BKBPP 2015 \\
& &
\end{tabular}

There are 29 TKI of Cianjur district for the past two years who involve various cases. In 2015 there are 26 cases and in 2016 there are 3 cases. ${ }^{15}$

One of the government supports in handling those problems is by forming working group of TKI family guidance ((POKJA BK-TKI) for support which in turns improves their life. The following are some indicators to determine the success of policy: first, how far the group target interest written in the policy is; second, what benefit target groups receive; third, how far the change wanted by the policy; fourth, whether the program is right, whether the location of the program is right; fifth, whether the policy has mentioned its implementer in detail; sixth, whether the program has been supported by sufficient sources. ${ }^{16}$

15 Radar cianjur, Rabu, May $11^{\text {th }}$ 2016, "Duh... 29 TKI Cianjur Bermasalah", available on website: http://jabar. pojoksatu.id/cianjur/2016/05/11/duh-29-tki-cianjurbermasalah/, accessed on January $6^{\text {th }} 2018$.

16 Tedi Sudrajat and Agus Mardianto, "Hak Atas Perlindungan dan Pelayanan Kesehatan Ibu dan Anak (Implementasi Kebijakan di Kabupaten Banyumas), Jurnal Dinamika Hukum, Vol. 12 No. 2, January 2012, p. 265, 
The model of TKI family protection in $\mathrm{Ci}$ anjur is implemented by program of society economic empowerment. One of the programs is to increase the Role of Women towards Healthy and Prosperous Family (P2WKSS in Indonesia). There are 8 (eight) integrated programs including education, medical, purchasing power, safety, women empowerment, society and institution participation. Through P2WKSS hopefully women can independently help in-crease family income. ${ }^{17}$

In 2017, Cianjur Regency has made a Regent Policy that is put in law of Regent of Cianjur decision Number 476/5596/DPPKBP3A/ 2017 on Formation of Working Group TKI Family Guidance. One of divisions in TKI Family Guidance is economic empowerment that involves: first, facilitate various implementations of entrepreneurship training that are technical managerial and technical financial management, second, guiding their business development; third, exploring the cooperation with small, medium and large companies and also with financial institution to develop the TKI family business; fourth, trying to provide initial capital for TKI family; fifth, intensifying the religious figures' role to give spiritual coaching; sixth, Implementing the family physical endurance training by providing adequate nutrition and healthy way of living. For instance, Regional Leader of Aisiyah Cianjur activity that trains TKI family in making handicrafts.

\section{Technique of Implementation for TKI Family Protection in Cianjur Regency}

Technique of implementation is conducted by increasing the number of villages to be the location of P2WKKS. They are Karyamukti village, Cibeber District, Kampung Pasir Kamuning village and Babakan Asem, Karang Nunggal village, Cibeber District, Cihea village Haurwangi District. Those villages will participate in evaluation contest of the Enhancement of Wo-

17 Pikiran Rakyat, November $11^{\text {th }} 2009$, “P2WKSS Membangun Kemandirian Kaum Wanita", available on website: http://www.pikiran-rakyat.com/jawa-barat/2009/11/ 11/101235/p2wkss-membangun-kemandirian-kaumwanita, accessed on August $18^{\text {th }} 2017$. men' Role toward Prosperous and Healthy Family (P2WKSS) in West Java Province. Besides the establishment of P2WKSS, there is also TKI Family Guidance Policy (BK-TKI). It was established in level of region, district, and village that is called as POKJA BK-TKI. In society level, it is called as TKI Family Guidance Group set by head of village.

The preparation in establishing TKI Family Guidance refers to general guidelines of TKI Family Guidance in Article 6 of State Ministry of Women Empowerment and Child Protection Republic of Indonesia Regulation Number 20 Year 2010 on General Guidelines of TKI Family Guidance. It comprises first, facilitate, socialize and advocate the importance of TKI family guidance; second, seek cooperation; and third, form a working group. Membership of working group involves elements of government and society. Working group is in charge to plan the action and form family groups of TKI family who will be given the coaching.

Formation of BK-TKI is working group responsibility in level of District/City. The implementation of the formation is done by working group in level of village assisted by working group in sub-district level, then it will be set in Regent of Cianjur Decree. The steps to implement BK-TKI are: economic empowerment, resilience and family welfare, and child protection. Those three divisions are intended to protect TKI and their family especially their children. The child protection of migrant workers must be based on general principles of child protecttion. ${ }^{18}$

The steps in forming BK-TKI are; set the target, form the group, coach the group of BKTKI in village level, implement the counseling and material activities of BK-TKI. To set up the target of BK-TKI is done by: first, collect the TKI family data and Potential Region; second, analyze the result of data collection; third, determine TKI Family, TKI applicants, Purna Tenaga Kerja Indonesia whose family works as TKI in

\footnotetext{
18 Riris Ardhaniswari, Waluyo Handoko, and Sofa Marwah, "Pembentukan Model Perlindungan Anak Buruh Migran di Kabupaten Banyumas", Jurnal Dinamika Hukum, Vol. 12 No. 1, January 2012, p. 9,
} 
Indonesia or abroad to become Member of TKI Family Working Group (maximum 20 members each group). Human resource management is one of processes to utilize humans as worker appropriately. It aims to make use their physical and psychological potentials as much as possible to achieve the organization or institution's target. ${ }^{19}$ Therefore, forming a group involves setting the first initial meeting of family of TKI in village to group up, choosing a group coordinator of TKI Family Working Group, planning the group work (regular meeting, activity and others). Family guidance group of TKI in village including group meetings and mentoring should be well-man-aged.

The formation of working group is held by Regent. The working group has the following tasks; first, organize operational plan of Group of TKI Family Guidance; second, organize and develop the implementation of TKI Family Guidance activity; third, facilitate TKI Family Guidance in level of district and village; fourth, facilitate the group formation of TKI Family Guidance; fifth, develop counseling materials for TKI Family Guidance; sixth, give a suggestion for supporting activities; seventh, do monitoring and evaluating every semester; eight, make a report of implementation of TKI Family Guidance in Cianjur Regency.

The output indicator from Family Guidance are explained as follows: A better welfare of TKI Family in village (incomes, education, health, housing, clean water, etc), increase the number of participants in TKI Family Working Group Coaching, decrease number of family problems such as domestic violence, human trafficking, divorce, fulfillment of children rights, and the issue of Regency and Village regulation to child protection of TKI family.

The activities are expected to be the following: the group working formation of TKI Family Guidance, formation of TKI Family Guidance, the availability of mentor/cadre of TKI Family Guidance, the meetings of TKI Family Guidance achieved, improvement of the active

19 Johannes Suhardjana, "Kualitas Sumberdaya Manusia Menentukan Kemajuan Suatu Negara", Jurnal Dinamika Hukum, Vol. 9 No. 3, September 2009, p. 272. participation from family of TKI Family Group Guidance. Currently in Cianjur District, TKI Family Group Guidance that been formed are 6 (six) districts and 7 (seven) villages. Those are Cilaku district (Sukasari Village), Cibeber District (Sukamaju Village), Pagelaran District (Gelar Anyar Village), Karang Tengah District (Maleber and Langensari Village), Bojong Picung District (Bojong Picung Village), and Sukaluyu District (Sukaluyu Village).

\section{Conclusion}

The law protection towards TKI family in Cian-jur Regency is implemented by formulating several local regulations intended to protect the society especially TKI. The protection involves placement of TKI overseas, human trafficking and child protection. Furthermore law protecttion is followed up by the decision making of Regent of Cianjur on forming a working group of TKI Family Guidance. It starts from district to village level through economy empowerment activity for TKI family. Technique of implementation for the guidance in Cianjur is conducted including and expanding village which runs the programme of The Enhancement of Women' Role Toward Prosperous and Healthy Family (P2WKSS) and forming group of TKI Family Guidance in Regency, sub-district and village level which is implemented in stages and inter sectors.

\section{References}

Adharinalti. "Perlindungan terhadap Tenaga Kerja Indonesia Irregular di Luar Negeri". Jurnal Rechtsvinding. Vol. 1 No. 1. April 2012. Pp. 157-173;

Agusmidah. 2010. Hukum Ketenagakerjaan Indonesia. Dinamika dan Kajian Teori. Jakarta: Ghalia Indonesia;

Ardhaniswari, Riris. Waluyo Handoko and Sofa Marwah. "Pembentukan Model Perlindungan Anak Buruh Migran di Kabupaten Banyumas". Jurnal Dinamika Hukum. Vol. 12 No. 1. January 2012. Pp. 1-14, DOI: 10. 20884/1.jdh.2012.12.1.14;

Baharudin, Erwan. "Perlindungan Hukum Terhadap TKI Di Luar Negeri Pra Pemberangkatan, Penempatan, Dan Purna Penempatan". Lex Jurnalica. Vol. 4 No. 3. August 2007. Pp 168-176.; 
Bintoro, Rahadi Wasi. Riris Ardhanariswari and Rahman Permana. "Implementasi UU No. 13 Tahun 2003 Tentang Ketenagakerjaan Bagi Tenaga Kerja Perempuan Di Kabupaten Purbalingga". Jurnal Dinamika $\mathrm{Hu}$ kum. Vol. 8 No. 3. September 2008. Pp. 231-237. DOI: 10.20884/1.jdh.2008.8.3. 79;

Butsi, Citra Berlian. Saleh Soeaidy and Minto $\mathrm{Ha}$ di. "Efektivitas Program Asuransi Tenaga Kerja Indonesia (TKI) Sebagai Upaya Pemenuhan Hak-Hak TKI (Studi Pada Unit Pelaksana Teknis Pelayanan penempatan Dan Perlindungan Tenaga Kerja Indonesia Surabaya)". Jurnal Administrasi Publik (JAP). Vol. 1 No. 7. Pp 1313-1322;

Endrawati, Netty. Perlindungan Hukum Terhadap Pekerja Anak di Sektor Informal (Studi Kasus di Kota Kediri). Jurnal Dinamika Hukum. Vol. 12 No. 2. May 2012. Pp. 270283;

Hartini, Sri dan Abdul Aziz Nassihudin. "Pengisian Jabatan Sekretaris Desa Di Kabupaten Banyumas (Studi Tentang Kebijakan Pengisian Jabatan Sekretaris Desa)". Jurnal Dinamika Hukum. Vol. 8 No. 1. January 2008. Pp. 13-20. DOI: 10.20884/1. jdh.2008.8.1.18;

Hartono, Sunaryati. 1991. Politik Hukum Menuju Sistem Hukum Nasional. Bandung: Alumni;

Nuraeny, Henny and Tanti Kirana Utami. "Legal Protection Against Children Who Are Victims Of Human Trafficking In Cianjur District Studied By Human Rights Perspective”. Jurnal Dinamika Hukum. Vol. 15 No. 2 May 2015. Pp. 172-177. DOI: 10. 20884/1.jdh.2015.15.2.344;

Nuraeny, Henny and Tanti Kirana Utami. "The Victim Handling Model of Human Trafficking through Economic Independence". Jurnal Dinamika Hukum. Vol. 16 No. 2. May 2016. Pp 120-124. DOI: 10.20884/1. jdh.2016.16.2.507;
Pihang, Herdy L. N. “Tanggung Jawab Perusahaan Jasa Tenaga Kerja Indonesia (PJTKI) Terhadap Perlindungan Tenaga Kerja Wanita". Jurnal Lex Et Societatis. Vol. I No. 5. September 2013. Pp 64-72;

Pikiran Rakyat. November $11^{\text {th }}$ 2009. P2WKSS Membangun Kemandirian Kaum Wanita. Koran Pikiran Rakyat. tersedia di: http:// www.pikiran-rakyat.com/jawa-barat/ 2009/11/11/101235/p2wkss-membangunkemandirian-kaum-wanita. Accessed on August $18^{\text {th }} 2017$;

Radar Cianjur, Wednesday, May $11^{\text {th }} 2016$, “Duh... 29 TKI Cianjur Bermasalah”, Koran on line Pojok Cianjur, tersedia di: http://jabar.pojoksatu.id/cianjur/2016/0 5/11/duh-29-tki-cianjur-bermasalah/, accessed on January $6^{\text {th }} 2018$;

Prihatin, S. Djuni. "Potret Buram Perlindungan Tenaga Kerja Indonesia”. Jurnal Ilmu Sosial dan Ilmu Politik. Vol. 10 No. 3. March 2007. Pp 325-341;

Sudrajat, Tedi and Agus Mardianto. “Hak Atas Perlindungan dan Pelayanan Kesehatan Ibu dan Anak (Implementasi Kebijakan di Kabupaten Banyumas)". Jurnal Dinamika Hukum. Vol. 12 No. 2. January 2012. Pp 261-269. DOI: 10.20884/1.jdh.2012.12.2. 43;

Suhardjana, Johannes. "Kualitas Sumberdaya Manusia Menentukan Kemajuan Suatu Negara”. Jurnal Dinamika Hukum. Vol. 9 No. 3. September 2009. Pp. 306-313;

Susetyorini, Peni. “Perlindungan Tenaga Kerja Indonesia (TKI) di Luar Negeri Oleh Perwakilan Republik Indonesia”. Jurnal Masalah-masalah Hukum. Vol. 39 No. 1. Maret 2010. Pp. 65-77;

Zulkarnaen, Ahmad Hunaeny and Tanti Kirana Utami. "Perlindungan Hukum Terhadap Pekerja Dalam Pelaksanaan Hubungan Industrial". Padjadjaran Jurnal Ilmu Hukum. Vol. 3 No. 2. 2016. Pp 407-427. 